Katarzyna CHOLEWA

Akademia Rolnicza, Poznań

\title{
Wybrane zagadnienia prasy rolniczej na terenie Wielkopolski po 1945 roku i współcześnie
}

a terenie Wielkopolski, drugiego co do wielkości województwa, spra-
wy rolnictwa niemal od zawsze odgrywały kluczowa role. Do tego stanu rzeczy z pewnością przyczynia się fakt, iż znaczną część terytorium stanowią tereny o charakterze rolniczym, a ilość i jakość produkowanej tu żywności czyni region krajowym liderem w tej kategorii. Dowodem na zainteresowanie rolniczą tematyką jest również umiejscowienie Targów Rolno-Przemysłowych „Polagra - Food” i „Polagra - Farm”, działanie licznych ośrodków upowszechniających wiedzę rolniczą, zajmujących się doradztwem i promowaniem rolniczego postępu. Oczywiste jest, że warunki działania sektora rolniczego zmieniały się na przestrzeni lat - inaczej wyglądały zaraz po wojnie, inaczej dziś, a wraz z nimi zmieniało się oblicze wielkopolskiej prasy rolniczej. 60-letni czas jej funkcjonowania należy rozpatrywać w ścisłym związku z panującą sytuacją polityczną i dyktowanymi przez nią warunkami, w jakich działali rolnicy. A. Woś wyróżnia następujące okresy powojennego rolnictwa: okres powojennej odbudowy rolnictwa (1945-1949), okres forsownej kolektywizacji (1949-1956), nowej polityki rolnej (1957-1970), polityki przyspieszania rozwoju i poszukiwania nowej równowagi (1971-1980), okres narastającego kryzysu w rolnictwie (1981-1989) i transformacji ustrojowej typu kapitalistycznego (od 1990 roku) ${ }^{1}$.

Warunki powojenne z pewnością nie należały do sprzyjających jakiejkolwiek działalności o charakterze ekonomicznym czy kulturalnym, a wydawanie prasy rolniczej nie stanowiło pod tym względem wyjątku. Kiedy działania wojenne dobiegały końca, na wyzwalanych terenach zaczęły

1 A. Woś, Rolnictwo polskie 1945-2000. Prawnoporównawcza analiza systemowa, Instytut Ekonomiki Rolnictwa i Gospodarki Żywnościowej, Warszawa 2000, s. 10 . 
kształtować się struktury nowej powojennej prasy, a każdy z jej rodzajów miał swoją specyfikę. Prasa rolnicza w Wielkopolsce, podobnie jak na terenie całego kraju, związana była z działalnością Stronnictwa Ludowego, które opierając się na lewicowych grupach ludowych, wznowiło „Polskę Ludową” w Poznaniu, „Dziennik Ludowy” w Warszawie, „Głos Ziemi” w Olsztynie, „Dolnośląski Tygodnik Ludowy” we Wrocławiu, „Przyjaciela Ludu” w Krakowie oraz pismo społeczno-kulturalne „Wieś”. Nieco później Polskie Stronnictwo Ludowe, które zaczęło działać pod kierownictwem S. Mikołajczyka wpłynęło na powstanie kolejnych tytułów prasy rolniczej - „Chłopskiego Sztandaru” oraz „Gazety Ludowej”, a jego prowincjonalne organy utworzyły krakowski tygodnik „Piast” i poznańską „Gazetę Chłopską". Na terenie całego kraju z myślą o rolnikach drukowano tzw. błyskawice o skupie żywca, mleka, dostawach zboża itd. Wychodziły gazetki „Robotnik Rolny”, „Spółdzielnia Produkcyjna”, „Poradnik Ruchu Łączności Fabryk ze Wsią,3. Powstawanie pierwszej powojennej prasy rolniczej towarzyszyło przeprowadzaniu reformy rolnej, będącej jednym z przejawów wcielania w życie nowego modelu ustrojowego - socjalizmu. W celu tworzenia gospodarstw dla bezrolnych chłopów, wszystkie majątki o obszarze powyżej 100 ha powierzchni ogólnej, a także te powyżej 50 ha powierzchni ornej poddano parcelacji. Nowy system nie wpłynął jednak na zmianę struktury polskiego rolnictwa - podstawą pozostała własność indywidualna, choć tak wiele wysiłku włożono w tworzenie państwowej i spółdzielczej.

Pomijając wydawnicze trudności natury technicznej, na które składał się między innymi brak surowców i odpowiedniego sprzętu, uciążliwym znakiem czasu była cenzura, choć nie stanowiła przecież nowego wynalazku. Na przestrzeni wieków każda władza w mniejszym lub większym stopniu usiłowała mieć wpływ na treści, które za pomocą słowa pisanego przenikały do świadomości społeczeństwa, a początków tej tendencji dopatrywać się można już w starożytnym Rzymie. Odpowiedź na pytanie o przyczynę tego stanu rzeczy znajduje się choćby w wypowiedzi Emila Pierreta, cytowanego przez Tadeusza Kupisa, „kształcenie nie kończy się po opuszczeniu szkoły. Odbywa się ono dwojaką metodą: dobrowolną,

2 J. Łojek, J. Myśliński, W. Władyka, Dzieje prasy polskiej, Interpress, Warszawa 1988, s. 169 .

3 J. Lubiński, Lata 1945-1989, w: Media w Polsce w XX wieku: prasa, radio, telewizja, reklama, public relations, badania rynku, red. R. Gluza, Press, Poznań 1999, s. 34 . 
systematyczną... oraz mimowolną i przypadkową. Ta druga jest udziałem przygniatającej większości ludzi i uprawiana jest za pomocą literatury, teatru i dziennika. Najistotniejszym jednak źródłem kształcenia mas, źródłem obfitym i niewyczerpanym, rozpowszechnianym wszędzie i wszędzie wytryskującym - jest prasa" ${ }^{4}$. Z tego faktu zdawali sobie sprawę komuniści, którzy w latach 1944-1945 przejęli władzę w Polsce, a nie mogąc z oczywistych względów uzyskać dla niej poparcia, poza stosowaniem siły, starali się różnymi metodami wychować grono swoich zwolenników. Prasa, środek oddziaływania na świadomość społeczeństwa, nie mogła pozostać bez kontroli. I tak już we wrześniu 1944 roku dekretem PKWN określono zasady funkcjonowania Resortu Informacji i Propagandy mającego w założeniu stanowić centralną instytucję propagandową. Utworzono w nim sześć oddziałów - ogólny, prasowo informacyjny, radiowy, wydawnictw, propagandy masowej w kraju oraz propagandy zagranicznej. Na początku 1945 roku został on przekształcony w Ministerstwo Informacji i Propagandy ${ }^{5}$. Od stycznia 1945 roku rolę cenzury pełniło Centralne Biuro Kontroli Prasy przy Ministerstwie Bezpieczeństwa Publicznego. Funkcjonowało ono, mimo braku formalnej podstawy prawnej, jako że dopiero 5 lipca 1946 roku powołano na mocy dekretu Główny Urząd Kontroli Prasy Publikacji i Widowisk. Decydował on zarówno o powstawaniu nowych tytułów, jak i o treściach zawartych w tych, które już istniały. Każde pismo bez względu na to, czy było organem rządzącej partii, przyczyniało się do upowszechniania jej idei. Jak pisze D. Nałęcz, „działania Urzędu ściśle współgrały z takimi pociągnięciami, jak wykluczenie własności prywatnej z rynku prasowego, nacjonalizacja przemysłu poligraficznego i papierniczego, reglamentacja papieru drukarskiego, weryfikacja zasobów bibliotecznych" ${ }^{6}$. Dbano, aby wszystkie osoby zaangażowane w wydawanie tytułów prasowych począwszy od redaktora naczelnego, na pracownikach technicznych skończywszy przyczyniały się do utrwalania istniejącego porządku, a w żadnym wypadku przez swoją działalność nie poddawały pod wątpliwość jakichkolwiek odgórnych rozstrzygnięć.

4 T. Kupis, Dzienniki i czasopisma na polskim rynku prasowym, Ośrodek Badań Prasoznawczych RSW Spółdzielni „Prasa-Książka-Ruch”, Kraków 1975, s. 25.

5 A. Krawczyk, Pierwsza próba indoktrynacji. Działalność Ministerstwa Informacji i Propagandy w latach 1944-1947, Instytut Studiów Politycznych Polskiej Akademii Nauk, Warszawa 1994, s. 13.

6 D. Nałęcz, Główny Urzqd Kontroli Prasy 1945-1949, Instytut Studiów Politycznych Polskiej Akademii Nauk, Warszawa 1994, s. 18. 
Według R. Kowalczyka, ,służby bezpieczeństwa państwowego, zarówno ze strony rosyjskiej (NKWD), jak i polskiej (Ministerstwo Bezpieczeństwa Publicznego i jego terenowe agentury) tropiły wydawców, redaktorów, łączników, drukarzy i kolporterów nielegalnej prasy, która w ich opinii ośmieszała obecną rzeczywistość oraz zmierzała do zerwania dobrych sąsiedzkich stosunków z bratnim Narodem ZSRR" "7. Stosowano zarówno cenzurę prewencyjna, polegającą na kontrolowaniu tekstów przez uprawiony organ przed oddaniem ich do druku, jak i represyjną polegającą na kontrolowaniu treści już wydrukowanych przed rozpowszechnieniem i ewentualnej konfiskacie całego nakładu. Podczas jednej z narad, która odbyła się w lutym 1949 roku, cenzorom odpowiedzialnym za widowiska, choć podobne wytyczne dotyczyły zajmujących się innymi dziedzinami, nakazano interweniować, gdy „kwestia zawiera akcenty destrukcyjne, gdy sugeruje opieszałość w odbudowie i niewiarę w wykonywanie planów gospodarczych, gdy dezawuuje członków rządu naszego lub państw demokratycznych, gdy w grę wchodzą antydemokratyczne akcenty przedstawiające aparat państwowy jako zbiurokratyzowany i niechętny obywatelowi, kułackie ideały chłopskie, aktualne za sanacji”.8.

Skuteczną metodą wpływania na drukowane treści było bezpośrednie inspirowanie poszczególnych redakcji do zamieszczania na łamach pism wyznaczonych informacji, powodowanie by placówki cenzorskie stosowały zapis cenzorski dotyczący określonej treści, czy w celu kontroli nad całością rynku prasowego sporządzanie przez ministerstwa, urzędy wojewódzkie i placówki terenowe recenzji z prasy, mających na celu wychwycenie ewentualnych nieprawidłowości. Mniej skuteczne okazały się tzw. kolegia propagandowe, czyli w założeniu regularne odprawy redaktorów naczelnych wszystkich pism, które nie przynosiły pożądanych efektów, jako że nie wszyscy przedstawiciele środowisk dziennikarskich zamierzali się na nie stawiać ${ }^{9}$.

Dziennikarzami były wówczas osoby, które wykonywały ten zawód przed wojną, a z zawieruchy wojennej uszły z życiem i nie zdecydowały się na wyjazd z kraju. Wielu z nich udało się na emigrację, a później nie chcieli lub nie mogli wrócić ze względów politycznych. Część dziennikarzy zmieniła zawód, nie chcąc uczestniczyć w tworzeniu takiej prasy, jaką

${ }^{7}$ R. Kowalczyk, Wczoraj i dziś prasy lokalnej w Polsce, Agencja eSeM, Poznań 2002, s. 186.

${ }^{8}$ D. Nałęcz, op. cit., s. 22-23.

9 A. Krawczyk, op. cit., s. 36-38. 
dyktowały warunki polityczne. Nowi adepci zawodu kształcili się w Wyższej Szkole Dziennikarskiej, która wznowiła działalność w 1946 roku, w 1947 włączona została do Akademii Nauk Politycznych, a po dwóch latach przestała istnieć. Dziennikarzy szkolono też w placówkach naukowo-dydaktycznych, z których jedna funkcjonowała w Poznaniu ${ }^{10}$.

Czynnikiem, który nie sprzyjał czytelnictwu powojennemu był fakt, że duży odsetek ludności nie posiadał umiejętności czytania. $Z$ drugiej strony prasa rolnicza miała stosunkowo szerokie grono odbiorców, jako że w 1966 roku liczba ludności wiejskiej była równa liczbie mieszkańców miast. Dziesięć lat później proporcja ta uległa zmianie - 20 mln Polaków mieszkało już w miastach, a tylko 14,9 mln stanowiło społeczność wiejską $^{11}$.

W latach 1948-1953 wraz z umacnianiem się rządów komunistów następowało przyjmowanie sowieckiego modelu sytemu prasowego, co oznaczało jego centralizację. Z kolei w 1956 roku, zwłaszcza po wypadkach poznańskiego czerwca, zaszły widoczne, choć nietrwałe zmiany w czasopiśmiennictwie - w tym okresie ukazywała się prasa odpowiadająca rzeczywistym potrzebom społeczeństwa, zamiast tej, która służyła jedynie propagandzie i dezinformacji społeczności wiejskiej. Ta tendencja nie utrzymała się jednak długo i prasa zataczając koło wróciła do realizowania zadań, jakie jej już poprzednio wyznaczono. Jak pisze J. Lubiński, „po podwyżce cen mięsa i tłuszczów w październiku 1959 roku uzasadniała jej konieczność, prowadząc jednocześnie akcję nakłaniania chłopów do realizowania obowiązkowych dostaw żywca. Podawała przykłady świadczące o spekulacji żywnością. Popularyzowała technikę, pokazywała dorobek Polski Ludowej przy okazji XX-lecia, przekonywała chłopów do kółek rolniczych, zajmowała się aferą mięsną i akcentowała demokratyczność wyborów do Sejmu na początku 1961 roku [...]. Podkreślano awans chłopów z niewolnictwa burżuazyjnego do spółdzielni produkcyjnej. Życie składało się z nieustannych kampanii. Na przykład rolnicy cykl kampanii zaczynali od orki wiosennej, potem nadchodziła kampania siewna, sianokosów, żniwna, ziemniaczano-buraczana, a kończyli - orką zimową" 12 .

Uchylenie żelaznej kurtyny, kontakty z Zachodem i nowa sytuacja społeczno-polityczna zmieniły oblicze prasy rolniczej. Wprowadzono

10 J. Łojek, J. Myśliński, W. Władyka, op. cit., s. 155.

11 J. Łojek. J. Myśliński, W. Władyka, op. cit., s. 156.

12 J. Lubiński, op. cit., s. 35, 39. 
nowe regulacje prawne, zlikwidowano GUKPPW i zniesiono cenzurę. Konstytucja z 1997 roku stanowi, że „Rzeczpospolita Polska zapewnia wolność prasy i innych środków społecznego przekazu”. O ile wcześniej co do zasady wszelkie tytuły wydawane były przez podmioty publiczne, czyli spółdzielnie wydawnicze, organizacje społeczne czy inne instytucje państwowe najczęściej dotowane przez państwo, o tyle po przełomie wydawać pisma mogły już również osoby prywatne. Zaczął obowiązywać system rejestracyjny polegający na tym, że wydawanie dziennika lub czasopisma wymaga jego rejestracji w sądzie okręgowym właściwym miejscowo dla siedziby wydawcy. Konieczne jest złożenie wniosku zawierającego tytuł dziennika lub czasopisma, siedzibę i dokładny adres redakcji, dane osobowe redaktora naczelnego, określenie wydawcy, jego siedziby i dokładnego adresu oraz częstotliwość ukazywania się dziennika lub czasopisma ${ }^{13}$. Symbolem zezwolenia na działalność wydawniczą jest ISSN - pochodzący z języka angielskiego termin International Standard Serial Number, thumaczony jako Międzynarodowy Znormalizowany Numer Wydawnictw Ciagłych. Termin wydawnictwo ciagłe oznacza, że dane pismo nie ma sprecyzowanego zakończenia, ukazuje się pod wspólnym tytułem, częściami oznaczonymi kolejnym numerami bądź chronologicznie w określonych lub nieokreślonych odstępach czasu. Do wydawnictw ciaggłych w przypadku prasy rolniczej zaliczają się głównie dzienniki i czasopisma. Oznaczenie ISSN powinno być umiejscowione w widocznym miejscu, we wszystkich częściach dziennika czy czasopi$\mathrm{sma}^{14}$.

W nowej rzeczywistości wiele tytułów upadło, aby mogły ukazać się nowe. Zaczęły powstawać pisma, o których obecności decydowały prawa rynku, a nie odgórne decyzje władz. Wydawcy, chcąc sprostać nowym wymogom, musieli dostosować zarówno treść, jak i szatę graficzną pism do obowiązujących standardów. Gorący skład zastąpiono komputerowym i w miejsce druku wypukłego zastosowano druk płaski. Dzięki wykorzystaniu nowoczesnych technik polskie czasopisma zdołały zdobyć i utrzymać swoją pozycję mimo napływających z zachodu pism konkurencyjnych. Z pewnością przyczynił się do tego również fakt, że prasa rolnicza w prze-

13 Ustawa z dnia 26 stycznia 1984 r. Prawo prasowe, Dz. U. 1984, Nr 5, poz. 24 z późn. zm., art. 20 .

14 M. Barańska-Sereda, Obowiazki rejestracyjne wydawców ISSN, ISBN, w: Problemy organizacyjno-prawne prasy rolniczej, red. J. Sobczak, Centrum Doradztwa i Edukacji w Rolnictwie, Poznań 1995, s. 76-78. 
ciwieństwie do magazynów typowo rozrywkowych nie mogła być tak szybko zastapiona zagraniczną, gdyż model rolnictwa każdego kraju, zwłaszcza w latach transformacji różnił się w znacznym stopniu od pozostałych.

Nie sposób przeanalizować powstawania, funkcjonowania na rynku czytelniczym i ewentualnie zakończenia działalności wszystkich tytułów przeznaczonych dla rolników od czasów powojennych, warto jednak przyjrzeć się dwóm z nich, które odegrały znaczącą rolę w środowisku wiejskim.

Najbardziej popularnym pismem na wsi w powojennej rzeczywistości była wydana po raz pierwszy w 1952 roku „Gromada - Rolnik Polski”. Trudno ocenić, czy najbardziej poczytnym, bo w owych czasach nie zapotrzebowanie społeczeństwa decydowało o wielkości nakładu, ale odgórne przekonanie, że dane pismo powinno znaleźć się w każdym wiejskim domu. Fakt ten nie zaskakuje, skoro „Gromada-Rolnik Polski” pełniła zarówno rolę rzecznika polityki rolnej PZPR i ZSL, jak i funkcję agitacyjną. Wydawana była wprawdzie w Warszawie, ale trzeba o niej wspomnieć przy okazji omawiania prasy wielkopolskiej, bo i tutaj przyczyniła się w znacznym stopniu do upowszechniania czytelnictwa, a także dlatego, że jej korzeni można doszukiwać się również w Wielkopolsce. Otóż na tym terenie od 1846 roku ukazywał się „Wielkopolanin”, którego dorobek publikacyjny zakończył wybuch wojny. W roku 1947 pojawił się pierwszy numer pisma „Rolnik Polski”, które tematyka, doborem i rozmieszczeniem artykułów wyraźnie nawiązywało do „Wielkopolanina”. Redaktorem naczelnym był wówczas Antoni Olcha, wcześniej redaktor naczelny pism „Wieś i jej pieśń” oraz „Chłopi”, a resztę zespołu redakcyjnego stanowili przedwojenni dziennikarze, zajmujący się wcześniej podobną tematyką. W 1955 roku „Rolnik Polski” został przejęty przez partyjną Robotniczą Spółdzielnię Wydawniczą „Prasa” i połączony z pismem „Gromada”, wcześniej wysokonakładowym pismem dla małorolnych i średniorolnych chłopów powołanym z inicjatywy KC PZPR w celach propagandowych, zwłaszcza wyjaśniania polityki dotyczącej wsi i rolników. Dwa pisma połączone w jedno zaczęły realizować cele, do których wcześniej została powołana „Gromada”. Redaktorem pisma została Irena Grosz i pozostała na tym stanowisku niemal dwadzieścia lat. „Gromada Rolnik Polski” zaczęła wychodzić trzy razy w tygodniu w ponad milionowym nakładzie. Była to redakcja - instytucja, w której o obsadzie najważniejszych stanowisk decydowała partia, a motto brzmiało: „Nic co wiejskie nie jest nam obce”. Jako poradnik zawodowy ukazywała „dobre” 
przykłady pracy rolników, sołtysów i innych członków środowiska wiejskiego, którzy mieli stanowić wzór dla innych. Nie była zresztą w tym aspekcie odosobnionym przypadkiem, gdyż prasa tamtych czasów charakteryzowała się tendencją do kreowania bohaterów, którzy swoją heroiczną postawą i skupianiem się bez reszty na pracy przyczyniali się do realizowania wytyczanych odgórnie planów. Wiele miejsca zajmowały opisy organizacji społecznych i samorządowych, rad narodowych, spółdzielni i kółek rolniczych. Jeśli nawet poddawano jakieś zjawisko krytyce to tylko jednostkowy przypadek, a nie cały system władzy. Drukowano rozkładówkę „Agra”, dla młodszych „Aspiracje”, dla najmłodszych „Gromadę chłopców i dziewcząt". Jednym z istotnych elementów więzi z czytelnikiem były listy do redakcji, które najczęściej stawały się pretekstem do dyskusji. Czytelnicy pisali tym chętniej, że często obdarzana zaufaniem redakcja stawała sięjednym adresatem, któremu można było poskarżyć się na istniejący stan rzeczy. A przecież realia wsi niemal w każdych czasach dostarczały uzasadnionych powodów do narzekania choćby z tej przyczyny, że w porównaniu z rzeczywistością miejską były o wiele bardziej uciążliwe. Żalono się na trudności wynikające z biurokracji w urzędach, brak przemysłowych środków produkcji, trudności zaopatrzeniowe i niedoskonałości w funkcjonowaniu skupu rolnego. Korespondencja z redakcją stanowiła dla ówczesnych władz doskonały papierek lakmusowy wykrywający nastroje panujące w społeczności wiejskiej, których rozpoznanie pozwalało na adekwatną reakcję. W 1982 roku liczba prenumeratorów „Gromady” znacznie spadła, a w roku 1995 gazeta zakończyła swoją działalność. Trudno się dziwić, bo jeśli przyjrzeć się jej linii programowej to trudno sobie wyobrazić jej dalsze funkcjonowanie w nowych warunkach społeczno-politycznych. I tak z rynku prasowego, po blisko pół wieku obecności, niemal niezauważalnie zeszło jedno z najbardziej popularnych pism rolniczych ${ }^{15}$.

Pismem typowo wielkopolskim zarówno ze względu na pochodzenie, wydawanie, jak i wpływ na czytelników związanych z wielkopolskim rolnictwem był i pozostał do tej pory „Poradnik Gospodarski”, którego pierwszy numer ukazał się już w 1889 roku. Od początku istnienia aż do dziś jego myślą przewodnią jest pozytywistyczne hasło: „Czego dziś nie

15 Dane dotyczące pisma pochodzą głównie z pracy zbiorowej Gromada Rolnik Polski-Była taka gazeta, pod redakcją W. Borsuka przy współpracy H. Borzęckiego, Wydawnictwo Nowy Świat, Warszawa 2002, jak również z artykułów zamieszczanych w poszczególnych numerach. 
zrobisz, jutro nie dogonisz. A szkoda, jeżeli dzień jeden uronisz". Inicjatorem wydawania pisma był pierwszy patron Wielkopolskich Kółek Rolniczych w latach 1873-1900 Maksymilian Jackowski, a założycielem i pierwszym redaktorem Antoni Brownsford. W czasie przedwojennym odegrało ono ważną rolę w kształtowaniu świadomości narodowej, walki z zaborcą na polu ekonomicznym, a także rozwijaniu oświaty rolniczej. Do jego powstania przyczynił się fakt, że organizowane polskie stowarzyszenia i pisma, które w tamtym czasie tworzyły się i upadały połączyły się w 1871 roku w Centralnym Towarzystwie Gospodarczym, a w związku z tym zaszła potrzeba wydawania wspólnego pisma. „Poradnik” wydawano wprawdzie w Wielkopolsce, ale miał on zasięg ogólnokrajowy, docierał też za granicę. Pod koniec XIX i na początku XX wieku, posiadał debit na całą ówczesną Rosję, czytano go też w Szwajcarii i Austrii. W tamtych latach polski rolnik, który prenumerował „Poradnik” posiadał automatycznie ubezpieczenie swego gospodarstwa, co świadczy o tym, jak silne było to wydawnictwo i jak znaczne były posiadane przez nie fundusze. W 1914 roku redakcja wydała pierwszy Kalendarz Rolniczy w nakładzie 17000 egzemplarzy. W 1920 roku wydawanie tygodnika przejęła Wielkopolska Izba Rolnicza, a trzy lata później przy „Poradniku” powstała Rolnicza Księgarnia Nakładowa wyposażająca kółka rolnicze w biblioteki. Na przestrzeni kolejnych kilku lat wraz z „Poradnikiem” wydawane były dodatki „Rolnik Spółdzielca”, „Osadnik” i „Ognisko Rodzinne”. W okresie dwudziestolecia międzywojennego „Poradnik” był podstawowym środkiem informacji fachowej, a każdy członek kółka rolniczego zobligowany był do jego prenumeraty. Wybuch II wojny światowej przerwał ukazywanie się pisma. Wprawdzie w okresie powojennym pojawiały się pojedyncze numery, a w 1954 roku powstał „Mały Poradnik Rolnika” dla pięciu województw, ale ówczesna linia polityki uniemożliwiała regularne wydawanie pisma. W atmosferze tępienia samodzielnego funkcjonowania rolnika indywidualnego, niechętnie patrzono na prasę służącą jego edukacji i rzetelnemu informowaniu. W pierwszym numerze, który rozpoczął regularne ukazywanie się „Poradnika Gospodarskiego” pojawiły się artykuły poruszające aktualne wówczas problemy niedoboru żywności - Dlaczego brak nam zboża?, chorób będących konsekwencją warunków wojennych - Zwalczamy gruźlice ludzi $i$ zwierzat czy też podające informacje dotyczące organizacji administracyjnej - Drogq do usamodzielnienia sie jest samorzad rolniczy. W kolejnych numerach poruszano problemy obowiązkowych dostaw zbóż, spółdzielczości mleczarskiej, możliwości uzyskania kredytu na zakup sprzętu rolniczego, 
wznowienia działalności związków hodowców czy nabywania mienia z rozwiązujących się spółdzielni produkcyjnych. Relacjonowano też przebieg Międzynarodowych Targów Poznańskich, przybliżano modele gospodarki mlecznej w innych państwach, a także zamieszczano anonse na przykład o naborze do Męskiej Rocznej Szkoły Rolniczej w Grzybnie „dla młodzieży męskiej, pochodzącej z gospodarstw rolnych indywidualnych lub uspołecznionych”. W 1958 roku „Poradnik Gospodarski” wydawany dla Wielkopolski, Poznania i Ziemi Lubuskiej stał się organem Związku Kółek i Organizacji Rolniczych, w 1973 roku jego wydawanie przejęło PWRiL oddział w Poznaniu, a w 1991 roku Ośrodek Doradztwa Rolniczego Sielinko. W 1994 roku Urząd Patentowy RP nadał „Poradnikowi” świadectwo ochronne. Późniejsza tematyka „Poradnika” to między innymi budownictwo wiejskie, prawo własności i kwestie z nim związane, nawożenie gleby, ochrona roślin i żywienie zwierząt, obecnie często w aspekcie nowych uregulowań unijnych. Autorami artykułów zamieszczanych w „Poradniku Gospodarskim” są pracownicy naukowi Akademii Rolniczej im. Augusta Cieszkowskiego w Poznaniu, Akademii Ekonomicznej w Poznaniu, pracownicy zakładów naukowo-badawczych, instytutów doświadczalnych oraz Ośrodków Doradztwa Rolniczego. W 1999 roku minister rolnictwa i gospodarki żywnościowej przyznał Ośrodkowi Doradztwa Rolniczego w Sielinku dyplom w dowód uznania za kontynuację 110 letniej tradycji wydawania „Poradnika"16.

Doradztwo płynące z fachowych pism ponad wszelką wątpliwość jest rolnikom potrzebne, nie tylko tym, którzy prowadzą gospodarstwo na wielką skalę. Zdarza się, że nawet uhonorowani licznymi wyróżnieniami za wzorcową działalność o charakterze rolniczym popełniają błędy, wynikające z pomijania fachowych porad, co w konsekwencji prowadzi do strat finansowych, bądź obniżonej jakości wyrobów.

\section{Summary}

The paper presents social and political conditions affecting the emergence and existence of the agricultural press in Wielkopolska from the end of World War II to the opening of the iron curtain. The press which emerged after 1945 faced numerous prob-

16 Przedstawiając „Poradnik Gospodarski” autorka korzystała z informacji udzielonych przez redaktora naczelnego T. Szalczyka, zastępcę redaktora naczelnego W. Trawińskiego, materiałów redakcyjnych oraz artykułów publikowanych w poszczególnych numerach pisma. 
lems ranging from technical difficulties related to the shortage of equipment and materials, to censorship. The presence of censorship was a consequence of the political situation of the country as the new governing party was unable to win social support for its activities and had to resort to indoctrination of society. Consequently, for many years the press served the main purpose of disinforming citizens and explaining government decisions. On the other hand, however, correspondence with the readers was a 'litmus paper' of the attitudes of rural society which helped to promote the undertaking of appropriate steps at the central level. The paper outlines censoring institutions and the scope of their operations. The opening of the iron curtain contributed to radical changes in the press market. It was no longer up to the state to decide what titles should be established and published, but to the mechanism of the free market. New editors had to adapt both the graphic aspect and content of their magazines to new standards in order to survive in the face of the inflow of attractive titles from the West. It is impossible to analyze the history of all agricultural magazines published in Wielkopolska since 1945, thus the paper focuses on two, significant ones. „Gromada - Rolnik Polski” [community - Polish farmer] was not an original Wielkopolska publication, but it cannot be neglected in the presentation of the post-war agricultural press as it was the most popular magazine reaching practically every rural household. „Poradnik Gospodarski” [farmer's guidebook], on the other hand, originated from Wielkopolska both geographically and ideologically, as since the very beginning it referred to the positivist ideals that were so popular in this region. Its publication was broken by German occupation, yet it was later resumed to continue until the present day. 